\title{
The values, perception and attitudes of potential domestic tourists regarding the medical tourism offer of Romania
}

\author{
ILE Larisa-Florența ${ }^{1}$, HOLOSTENCU Luciana-Floriana ${ }^{2}$, ȚIGU Gabriela ${ }^{3}$, DIACONESCU Vlad $^{4}$
}

Editor: Constantin MUNTEANU, E-mail: office@bioclima.ro

Corresponding author: ȚIGU Gabriela, E-mail: gabriela.tigu@ase.ro,

\section{1,2,3,4. "Bucharest University of Economic Studies", Bucharest, Romania}

\section{Abstract}

Introduction. Apparently medicine and tourism have represented for a while distinct domains, both in terms of research and even in popular culture. While medicine is widely known as dedicated exclusively to healing and treating patients suffering from various diseases, tourism, popular since ancient times in relation to healing, is based on a person's motivation towards obtaining a pleasant experience in optimal conditions that already require the existence of a good state of health. Considering the emergence of new challenges in medicine, mostly in terms of demand, there is a phenomenon of directing preferences or needs in order to obtain medical services in a relaxing touristic environment. Due to the rapid development of medical tourism, we consider opportune to study this phenomenon, both from the perspective of a social and economic impact and from the need to reorganize the tourism activity, emphasized with new forms and modern concepts.

Material and method. As a limited number of research can be found related to medical tourism, and generally covers travelling for medical treatments or interventions, and also a few publications are dealing with theoretical aspects of this form of tourism, the main purpose of the article is to bring a scientific contribution to the global field of medical tourism, especially regarding the tourist expectations and attitudes towards an internal medical tourism offer. Using a quantitative research methodology, we aimed to achieve the following secondary objectives: identifying the interest, intention and reasons of respondents to practice medical tourism, establishing the level of confidence in the medical specialization of certain cities, assessing the level of knowledge and general perception on a treatment specifics in spa resorts structured in galaxy clusters.

Results and discussions. Focusing on both national and international research, we have reached the conclusion that there is a lack of specific statistical indicators to analyze or compare the phenomenon of medical tourism. The shortcomings that are considered in the research may be caused mainly by inconsistencies of defining different concepts related to medical tourism or the confusion generated by the use of terms specific to medical or health tourism. Thus, the main objective of our research is to identify relevant aspects regarding the values, perception and attitudes of potential domestic medical tourists towards Romania's medical tourism offer.

Conclusions. There are certain limitations to our research, but it can surely become a basis for further developments regarding galaxy clusters and their impact in relation to a tourist's needs.

Keywords: medical tourism, spa resorts, medical providers, medical services demand, balneary tourism,

\section{INTRODUCTION}

The rapid evolution of international tourism has been particularly influenced by technological progress and the improvement of life quality. Among them, we can distinguish: means of transport, increasing accessibility (mainly by air), diversification of tourism offer, social and political information and communication as well as adopting and developing social digital technology on a large scale (1).

Estimated as a branch of tourism, based on the economic sectors, health care, and tourism, medical tourism contributes ,to the health preservation and recovery in general and the good feeling in particular, by applying certain authorized medical services", as established by the National Conference of Health, in Rostock - Germany, in 20013 (2). At the same time, according to Bookman and Bookman, in 2007 (3), medical tourism does not mean just a kind of travel aiming to health improvement, but a section of trade services, as a consequence of joining two economic sectors: tourism and medicine. Medical tourism has been internationally generated by the tourist flows in developed countries (like in Western Europe, Canada, USA,) who have chosen to 
travel for health recovery to the developing countries, which can offer quality services at a discount price, a reduced waiting time, or including unavailable special services in their country of origin (4). Such travels have initially started from acquiring international medical services; still, during the last years, they have been included in the tourist services packages as combined with air transport services, transfers packages from the airport to the clinic, or the hotel, accommodation, and food services, or available optional trips. Aware of the huge economic benefits these type of travels can bring, two kinds of countries (developed and developing countries) have decided to promote this form of tourism by adopting national strategies and policies that could highlight the qualities of medical tourist destinations, consequently ranging them among the new world medical tourist destinations. Some of the most attractive medical tourist destinations are specially remarked, like India, Thailand, Singapore, Malaysia, Philippines, Cuba, Costa Rica, Argentina, Africa, Jordan, Turkey, as well as other Eastern European countries like Poland, Hungary, or Romania. (3).

\section{Related work}

The demand and supply analysis on the tourist market implies clarifying some important aspects, as the lack of reliable data comparable and based on evidence (5); the consequence comes in the difficulty to emphasize the country-level performance, destinations, and even entities like medical providers.

On the European level, we can anticipate the increase of medical services demand, as a result of introducing the „ePrescription and eDispensation” systems; they can allow the UE citizens to profit from the medication recommended by the physician in the resident country, available in the drug stores of the respective country. We can digitally access the electronic files of the patient, offering information about different important health aspects (allergies, previous conditions, medication, or surgery) (6) within the same program including electronically collected data. (The European Health Registry). This is an important aspect necessary for access to medical services abroad.

The health tourism market can be seen as a „continuum that reflects different sub-segments of requirements and interests" (7) The continuum approach of the consumer demand in health tourist supplies, according to Acorn Consulting (7), implies the existence of two poles: one 'soft', demanding high-quality wellness services, healthy food, walks in nature, fitness facilities, cosmetic services and relaxing massage. The other one is a 'hard', containing those who access invasive services and surgery, or medical treatment. Tourists preferring the spa services, cosmetic treatments, and other therapies, as well as treatments based on sludges, or water healing properties are permanently paid attention.

Romania is remarked for its health tourism, not only for the spa climatic resources but also as a competitive medical tourist destination. Compared to other countries in EU, the Romanian medical tourism is famous for its definite connection with the existence and exploitation of some significant spa climatic resources, the long experience in treating based on natural resources, and also for its innovative antiaging curative produces, invented by the Romanian doctors Ana Aslan and IonescuCălinești: Gerovital, Aslavital, and Pell-Amar (8).

Within the current context of globalization and creating the phenomenon of medical tourism, Romania has become one of the countries offering medical services to international patients, taking profit of its advantage of holding more than a third part of the accommodation capacity in city areas where private clinics of an international competitive medical offer are performing. Ranging the Romanian climatic spas as services providers and connecting them with the regional city medical offers could contribute to extending the tourism segment by associating foreign tourists in search of cheap attractive medical services, quality, and redirecting the existing tourists towards prevention and wellness medical services.

Romania corresponds to the European tendencies of growing the mobility of the patients who are looking for accessible medical services; at the same time, it embodies a destination for medical tourism and a source for other medical destinations, generally West European countries. The European legislation (9) facilitates easy access to the medical services provided by the countries within Western Europe and encourages cooperation with the respective countries, mostly with the neighboring states by developing certain mutual programs on the bordering regional level.

The Romanian medical tourism relies both on the medical services offered by private clinics and 
hospitals placed in the large cities and on the balneary tourism, deeply originating from natural, mineral resources and thermal waters, pits, saline, salt-water lakes clay, thalassotherapy, air therapy, used to treat different diseases like rheumatism, respiratory and cardiovascular conditions, internal diseases, etc.

According to The Romanian Medical Tourism Association, the offer is attractive for international patients for: dentistry, esthetic surgery, ophthalmology/ LASIK surgery, interventional cardiology, orthopedic surgery, other surgeries, CT and MRI scans, or recovery spa treatment (10). The most visited cities for medical tourism are Bucharest and other important cities in the country, served by functional airports like Cluj-Napoca, Timișoara, Târgu Mureș, Sibiu, Constanța (11). Even that countries are looking to focus on international tourism due to their positive influence over the balance of payment, national tourism stays as the main type of tourism, representing an important instrument for the regional economic development and flourishing (12).

Considering the positive influence upon the domestic medical services offer in general, generated by the abroad medical tourism providers in competition (13), neglecting the first one could lead to an incomplete perspective over the demand and offer generally applied in tourism.

Brokaw, quoted in Balogu and McClearly (14), says that 'before using the image to influence behavior, it is important to understand what is influencing the image; consequently, the identification of certain influencing factors regarding the image perception should become useful by associating them with the suitable segment of the market'. By doing this, we are looking to research and identify the possible differences between the image created by the tourist and its projection made by the respective destination. 'In this endeavor, we need to apply certain methods as well as statistical, mathematic, and economic models(patterns). According to $\mathrm{Li}$ and Hudson's opinion, we may notice some investigation deficiency related to customers, their attitudes and beliefs, faced to the concept of medical tourism. This is to be applied mainly for domestic medical tourism at the researching level (13).

Within the present article, we are going to study the results obtained from survey-based research regarding the image (perception) of the Romanian products and the touristic destinations, as perceived by the potential domestic medical tourists.

Two approaches are made to consider the image of a certain destination: a cognitive one, based on the functional, structural, or physical characteristics of the destination- and an emotional one, pictured at the level of emotions and feelings generated by a destination on individuals (15). The research has been focused on the statistical movement and interpretation concerning both the Romanian medical tourist offer, as well as attitudes of trust, interest, and choices expressed by the respondents.

\section{Methodology}

The research is based on the unrepeated random simulated survey method offering the possibility to get information by studying part of a collectivity we are looking to. This method can offer important information regarding the potential domestic tourist's particular attitude and behavior.

The main advantage of the survey resides in the possibility of getting information during a relatively short time, thus proving the accuracy and reduced expenditure.

The survey is targeting to identify some concerning values, perceptions, and attitudes of the potential medical domestic tourist concerning the medical tourist offer in Romania.

Performing this research supposes targets that need to be relevant and adapted accordingly. The following targets have been established:

a) identification of interest, intention, and motivation of the respondents in practicing medical tourism

b) setting the level of trust in the medical specialization of certain cities

c) evaluating the level of information and general perception of a particular treatment in balneary spas within the area of the galaxy clusters (the medical label)

d) identifying the travel options to certain medical tourist destinations (the map)

The surveyed collectivity represents the sampling base as well as the population on which the research results will be generalized. This is going to be applied to the Romanian inhabitants, consumers, or the potential domestic consumers of medical tourist produces (men and women). The observed unit is represented by the Romanian citizens grouped according to their residents in their country regions (Moldova, Dobrogea, Muntenia, București-Ilfov, 
Oltenia, Banat-Crișana), while the survey unit represents the place the information has been collected from, respectively, people over 18 years old included in the sample. The extraction of the sample implies both the determination of its volume based on the analysis of the researched population and the choice of the sampling procedure, the determination of the calculation estimators, and their theoretical accuracy. The volume of the researched sample depends on the collecting level of homogeneity, the probability of error, the probability of the guaranteed results, the time resources for the data collection, and the budget size.

If we consider the guaranteed probability of the results to be $95 \%(z=1,96)$, then the volume of the sample will be:

$$
n=\frac{z^{2} \cdot p[1-p)}{\Delta_{w}^{2}}=\frac{1,96^{2} \cdot 0,5[1-0,5)}{0,0 \mathrm{~B}^{2}} \approx 1110 \text { persons }
$$

for the $\Delta= \pm 3 \%$ error, knowing that $\mathrm{p}=0,5$ represents the proportion of the favorable case, that is the potential tourist out of the whole population.

Taking into account that the tourists show a dynamic collectivity, the applied type of sample represents the nominated one, considering both the dynamics of the questioned operators and the online completing the survey questions. The obtained information proves a higher rate of confidence. The criteria by which subjects have been selected follows the sample random principles; to diminish the selection error, the sample volume could not possibly be raised due to both financial and organizing reasons; consequently, a maximum allowed error of 3\% has been accepted. The interviews have been applied by two methods: taken by the operators either at the residence, the working place of the respondents, or online, based on the informatic application. The results of the questionnaire have been processed by applying the Microsoft, Excel, and the SPSS programs.

To validate the surveyed areas studied in the questionnaire, have been identified the first 11 regional cities of residence also representing university centers in Romania. The main balneary spas have been identified around them, within a previously established area of approximately $100 \mathrm{~km}$ away from the city. They were selected from the list of touristic spas of national interest, certified as balneary spas too. To possibly identify them with the Developing Areas of Romania and also for geographic reasons, the $100 \mathrm{~km}$ distance of certain areas has been modified up to a maximum of 150 $\mathrm{km}$ from the city. This allowed including them within a developing area of spas administrated under the jurisdiction of some other regional counties (Vatra Dornei, Pucioasa, Amara). The final goal of the geographic cluster has meant creating a map of destinations of a galaxy type, gravitating around a medical and university center of a city. The galaxy cluster is defined as:

$\checkmark$ a group of similar objects that grow together or depend on each other, or a group of people or things that are close to each other;

$\checkmark$ a group of similar things that are close to each other, in a confined space (dictionary.cambridge.org, 2018);

$\checkmark$ a group of similar things or people who are positioned or appear together, in a close relationship (oxforddictionaries.com, 2018);

Consequently, the 11 medical tourist area galaxy cluster types representing a consistent part of our paper are illustrated in Table 1. Medical cities and the balneary areas around them have been the foundation of our questionnaire; from this point of view, it aimed to identify the knowledge and perceptions about the types of medical affections for which these areas are popular. It also aimed to evaluate the respondent's level of confidence to assign a certain city according to the way of treating special medical affections. A very important aspect resulting from the replied questions is the medical label the respondents are eager to put on each cluster.

\section{Results and discussion}

Data collecting is based on the replies to the questionnaire applied to a sample of 1110 respondents on the whole Romanian territory out of all Development areas. 93\% of the respondents have confirmed that they are disposed to travel to another Romanian city. Also, they were offered medical tourist services in addition, during their staying visits to points of interest, attending local events city tours, trips, etc.) The importance of this offer has been obtained by the 'Semantic Differential' scale, from 1(unimportant) to 7 (very important), with an average score of 5,31. Both results finally referring to the respondent's disposition for medical traveling and their option for tourist services during their medical stay are reflecting that the Romanians are open to access medical tourism in Romania.

\subsection{The perception of the specialization of a}


medical city. Assigned confidence value.

According to the conclusions of this survey (fig.1), the most powerfully perceived cities when it comes to the confidence in treating cardiovascular diseases are Bucharest (37\%), Târgu Mureș (25\%), ClujNapoca $_{x x}$ (23\%). The orthopedic traumatic conditions are perceived as best treated in Bucharest (49\%) and Cluj-Napoca (20\%). Oncology treatments are $49 \%$ available in Bucharest and 39\% in ClujNapoca, representing the two cities patients are definitely in favor of (fig. 2). The rest of the cities represent under 3\% each when talking about the full number of the respondents. Plastic surgery medical and esthetics services are mostly perceived (71\%) as being best represented by Bucharest, while the recovery medical services, physical medicine, and balneology are estimated as best represented by Oradea (33\%). Close to Oradea, in the medical specialty "Recovery medical services, physical medicine and balneology" there is a high value of trust in Bucharest (24\%) and, in the third plan, in Constanța (14\%).

\subsection{The influence of the region of residence in trusting a medical city}

To increase the respondent's perception and trust in the medical specialization of certain cities, we have decided to study to what extent the area of residence can influence the confidence in the medical cities pointed by the survey.

For the analysis of the interdependence between the region of residence and the level of confidence in a certain city, we used the test whose values calculated for each variant of domicile and medical specialization (treated condition) greater than the critical value of 43.77 and the critical probability value Asymp. Sig. (2-sided) of 0.000 lower than the significance threshold of 5\%, demonstrates that there is a significant interdependence between the respondents' home region and their trust in a medical city. When analyzing the region of residence, we must also take into account the boundaries of the neighborhood, when the point of interest (the medical city) is located geographically near the area where the respondents live. Thus, we could identify the following cities:

- Sibiu and Brasov as trusted by the inhabitants of Transilvania, and also by those in Muntenia and Oltenia (the areas that have been studied together); still, we can appreciate Oltenia as mainly influencing Sibiu, while Muntenia - Brasov.
- Târgu Mureș and Cluj-Napoca, trusted by the inhabitants of Transilvania, as well as those in Banat and Crisana.

- Constanta, trusted by the people in Dobrogea and those in Muntenia ( the Muntenia - Oltenia areas). The respondent's confidence in the other cities (Bucharest, Oradea, Craiova, Iași, Arad, Timișoara) is strictly associated with the area of residence in the respective city.

\subsection{Perception of types of diseases possibly treated within specified clusters}

According to a literature review, we have identified the main types of diseases treated in the balneology spas of each cluster. The applied questionnaire has focused on the respondent's perception of the main disease they associate with the cluster.

The Moneasa cluster is the only area where the 'I don't know' reply options are 50\%. Consequently, we have appreciated that no medical label can be put on this area.

As for the Muntenia cluster, Bucharest is remarkably imposing its name as a cardiovascular center over the surrounding area. The therapeutic profile of the balneary spas inside the cluster is not known by the respondents.

The Moldova cluster is appreciated for treating digestive and respiratory diseases.

The Center Cluj cluster is first popular for its first therapeutic indications and labeled as having rheumatic specificity, while secondly, for a high rate of confidence in cardiology (a condition not included in the therapeutic indications of the resorts in the area). In this case, the city center, ClujNapoca, was strong enough to influence the cluster second label, because it enjoys high confidence in the specialization in cardiology.

The Banat cluster is correctly associated with the treatment of rheumatic diseases specific to the Herculaneum Baths, but the cardiovascular profile of the Buzias resort is not known. The Center Mures cluster receives the label of specialization in the treatment of gynecological diseases, specific to Sovata resort, and secondly, it is identified the cardiovascular specialization, for which the city center, Târgu Mureș, is recognized.

The therapeutic imprint of Sovata resort on the cluster is much stronger than that of the cluster center and Vatra Dornei resort (both with cardiovascular profile). Brasov cluster center is appreciated mainly for treating rheumatic diseases, 
but not representative of the region. Covasna comes next as ranged by the answers, consequently considered not sufficiently popular for its medical benefits. The Oltenia cluster is regularly specialized in rheumatology. Secondly, Călimanești-Căciulata is also recommended as one of the clusters due to digestive treatments. Crișana is correctly associated with rheumatic diseases treating as the main option, but it's also recommended in treating orthopedic traumatic conditions and neurology. We may consider confusion between the last two is possible in the region.

The West of Arad is not enough popular for treating some special diseases, as pointed by the $52 \%$ replies of „I don't know”. Even if 9\% of the respondents are correctly labeling the area, we still consider it as not enough to associate it with a medical cluster. The Sibiu cluster comes first for rheumatic treatment, but the second option differs from the one registered in the therapeutic recommendations of the resorts. The term "Ocna" from Ocna Sibiului may generate confusion that leads to the association of the area with the treatment of respiratory diseases (the second therapeutic indication is related to posttraumatic diseases). The Sea-side cluster is correctly associated mainly with treating rheumatism, while the orthopedic traumatic conditions treatment can be linked with the second indication of the area, that is the post-traumatic treatment.

\subsection{The travel motivation for medical reasons and disposition for the traveled distance}

The general factors that influence travel for medical purposes such as trust, safety, availability were the basis for constructing the answers to the question on the reason that determines the respondent to travel to another locality to obtain medical services. According to the survey results, the most important reasons are the medical doctor the respondent trusts $(42 \%)$, the unavailability of a particular medical specialty $(21 \%)$, a reputable clinic $(19 \%)$, and the second medical opinion (16\%) (fig.3). For a more detailed picture of the reasons for traveling for medical purposes, we chose to study whether the gender of the respondents influences the motivation for the trip. By using the Pearson Chi-Square test, we analyze whether there is an interdependence between the motivation of the trip for a medical tourist stay and the person's gender (table 2). According to the results, $37,5 \%$ of them trusting a famous clinic are men and $62,5 \%$ are women. As for trusting a doctor, $26,1 \%$ are men and 73,9 \% are women. The second medical opinion is relevant for $82 \%$ of women and $17,1 \%$ of men (Table 3 ). Given the result of $\chi^{2}$ with the value of 23,146 , higher than the critical value of 9.49 and the critical probability value of Asymp. Sig. (2-sided) of 0.000 lower than the significance threshold of $5 \%$, we conclude that there is significant interdependence between gender and motivation to travel for medical purposes. Another method we use is the Anova technique (table 4) applied to the groups of respondents to find out if there are significant differences among them.

The analysis of this interdependence starts from two hypotheses:

The null hypothesis $\left(\mathrm{H}_{0}\right)$ by which we state that "There are no significant differences between the groups of respondents according to their gender in terms of motivation to travel for medical purposes" (Gender does not significantly influence motivation).

The alternative hypothesis $\left(\mathrm{H}_{1}\right)$ affirming that „There are significant differences between groups of respondents by gender in terms of motivation to travel for medical purposes" (Gender significantly influences motivation).

Considering the value of the Fisher test $(\mathrm{F}=15,423)$ higher than 2.99 and taking into account that the critical threshold Sig. of 0.000 is lower than the significance threshold of 0.05 corresponding to the $95 \%$ confidence level, we decide to reject the null hypothesis $\mathrm{H} 0$ and accept the alternative hypothesis H1, i.e., gender significantly influences the motivation for the medical trip.

Consequently, we realize that women are influenced by the medical doctor, while men keep a balance between a famous clinic and a trusted doctor. As for the disposition of traveling to a certain distance for medical services, most of the respondents are ready to travel for over $300 \mathrm{~km}(63 \%)$, while $13 \%$ for just a limited distance between 200 and $300 \mathrm{~km}$.

From the total number of respondents, 14\% appreciate a travel limit of $200 \mathrm{~km}$ and $10 \%$ do not wish to travel farther than $100 \mathrm{~km}$.

\subsection{Preferences regarding the way the trip is organized and the influence of age on it}

From the perspective of how to organize a tourist stay, we asked respondents to choose the preferred way of organizing a medical tourist stay, from three options: individual organization, organization 
through a travel agency, and other ways. These possibilities correspond to the information from the first part of this research, where privately organized travel is popular while applying to a travel agency a regular way in tourism- is vaguely represented.

The results of the survey are showing an option for privately organized travel $(54 \%)$, while travel agencies are preferred only by $45 \%$ of the respondents. By using the Pearson Chi-Square test, we chose to analyze whether there is an interdependence between the way the medical tourist stay is organized and the age (table 5). The results demonstrate that $57.2 \%$ of the respondents who have selected private arrangements are $25-55$ old, 58.2\% opt for organizing through specialized travel agencies, while the age group over $55(9.7 \%)$ in turn prefers organizing through travel agencies. As for those under 25, they prefer individual tourism (38\%). The value of $472.98 \chi^{2}$ is higher than the critical value of 9.49 and the critical probability value of Asymp. Sig. (2-sided) of 0.000 lower than the significance threshold of $5 \%$, indicates a significant interdependence between age and the way the stay is organized.

The analysis of the interdependence between the ways of organizing the medical stay and the factorial variable "age", is performed starting from the following basic hypotheses:

The null hypothesis $\mathrm{H}_{0}$ : There are no significant differences between the groups of respondents by their age in terms of how the medical stay is organized.

The alternative hypothesis $\mathrm{H}_{1}$ : There are significant differences between the groups of respondents according to their age in terms of how the medical stay is organized (table 6). Considering the value of the Fisher test $(F=10,116)$ greater than 2.99 and taking into account that the critical threshold Sig. of 0.000 is lower than the significance threshold of 0.05 corresponding to the $95 \%$ confidence level, the null hypothesis $\mathrm{H}_{0}$ is rejected and the alternative hypothesis $\mathrm{H}_{1}$ is accepted.

By applying the Anova technique we conclude that age has a significant influence on the medical travel organizing options (table 7). The graphical interpretation (fig. 4) of the obtained data implies the organization on the three analyzed age categories: under 25 years (corresponding to the population between 18 and 25 years), between 25 and 55 years (active population), and over 55 years (population in large part). According to the statistical data obtained, people over 55 prefer to organize a medical tourist stay through a specialized travel agency, while the other age groups prefer to organize their stay individually.

\subsection{Preferences regarding the way of financing the medical tourist stay and the influence of the level of education on this preference}

From the angle of preferences regarding the way of financing the medical tourist stay, based on the results of previous research we have introduced three options of financing this kind of travel: reimbursement through the National Health Insurance House (CNAS), reimbursement through holiday vouchers, reimbursement through private health insurance systems (concluded by the employer on behalf of the employee or concluded individually), reimbursement through the pension fund system, personal payment, and others ways.

The results interpreted graphically (fig.5) outline the major interest in supporting the financing of these medical tourist stays through the national health insurance system (54\%), followed by the holiday voucher system.

From the perspective of possible interdependencies between the level of studies and the preferences regarding the way of financing the medical tourist stay, we chose to use the Pearson Chi-Square test (table 8). According to the results, $63.2 \%$ of respondents, who have secondary education, chose the settlement through CNAS, while $22.7 \%$ of respondents, who have higher education, prefer holiday vouchers. Personal payment is preferred by respondents with secondary education $(50 \%)$, while private health insurance is of interest to both those with secondary education and those with higher education, but in a lower percentage, between $6.8 \%$ and $11.2 \%$. In this situation, the value of $\chi^{2} 68,413$ is higher than the critical value of 21.03 and the critical probability value of Asymp. Sig. (2-sided) of 0.000 lower than the significance threshold of $5 \%$, confirms that there is a significant interdependence between the level of studies and the method of financing/settlement of the medical tourist stay (table 9). For the analysis of the interdependence between the way of financing/settlement of the medical stay and the factorial variable "studies", we start from two basic hypotheses: 
The null hypothesis $\left(\mathrm{H}_{0}\right)$ by which "There are no significant differences between the groups of respondents according to the level of studies in terms of how to finance/settle the medical stay".

The alternative hypothesis $\left(\mathrm{H}_{1}\right)$ by which "There are significant differences between the groups of respondents according to the level of their studies in terms of how to finance/settle the medical stay. To determine the differences between the groups, we used the Anova technique (table 10).

Considering the value of the Fisher test $(\mathrm{F}=13,609)$ higher than 2.99 and taking into account that the critical threshold Sig. of 0.000 is lower than the significance threshold of 0.05 corresponding to the $95 \%$ confidence level, the null hypothesis (H0) is rejected and the alternative hypothesis (H1) is accepted. Therefore, there are significant differences between the groups of respondents according to the level of their studies in terms of how to finance/settle the medical stay.

The graphical interpretation of the obtained data involves the grouping on the three categories of education level: general, secondary and higher (fig. 6) and reflects the fact that the preferences of respondents with secondary education are mainly oriented towards the National Health Insurance House. Respondents with higher education do not prefer the same way of financing the medical stay and claim that personal payment is a suitable way to support the tourist trip for medical purposes, along with private insurance (paid by the employer or individual). Holiday vouchers are considered suitable methods of financing the medical tourist stay, both by respondents with secondary education and by those with higher education.

\subsection{Preferred method of information on medical tourism and the attitude regarding the forms of tourism to which medical tourism can be combined with}

From the perspective of how to inform respondents about medical tourism, we used the method of "ranking". The hierarchical ordering according to preference places in the first place the use of the internet and in the second and third places the recommendation of a medical doctor, respectively, recommendations of friends. The last three places are occupied by information through tourism fairs, radio-TV shows, and promotional materials, which confirms that the classic promotion, which works for other forms of tourism is not enough for the decision on medical tourist stay (table 11). To analyze the attitude of the respondents regarding the possibility of combining medical tourism, we used the scaling method semantic differential with three steps, a useful method in measuring attitudes and opinions. The result of the survey (table 12) brings to the fore spa tourism with a score of 2.76 , followed by the recreational and leisure tourism, with a score of 2.71. In the next places are cultural tourism (2.49) and ecotourism (2.43). According to the respondents, the forms of tourism with the lowest possibility of combination with medical tourism are shopping tourism (2.00) and religious tourism (2.05).

\subsection{Clusters' attractiveness and the ranking of the intention to visit}

One of the goals of this survey was to design a map of the most attractive clusters according to the visiting intention and, consequently, ranking the visiting areas the respondents are interested to go to on a medical tourist travel, as presented in table 13 . The applied scaling method was 'the rank order', with partial scores given in an increasing order. The final score in the hierarchy determines the first rank, which is the minimum in our case.

The most attractive cluster was built around the city of Cluj-Napoca, followed by Târgu Mureș area cluster and the one of Brașov. The first three positions show the importance of the country central area according to the medical tourist travel perception. The West and South-West of Romania, hierarchically presented on this map are those around the clusters of Timișoara and Oradea, on the fourth and fifth position; the last positions are taken by the clusters around the cities of Iași and Arad.

For a more detailed highlight of the distribution of cluster attractiveness, an association was made between the respondents' region of residence and the analyzed cluster destinations. According to the calculated tests, it is confirmed that there is a significant interdependence between the region of residence and the intention to visit the medical tourism clusters. The data processing highlights the preferences by regions of residence of the respondents and outlines the main destinations that can be considered of maximum attractiveness on a map of medical tourism.

According to the results, the respondents from Ilfov/ Bucharest prefer Crișana (22\%), Central Cluj (17\%), and the Sea-side $(10 \%)$. They also appreciated the area close to their residence (Muntenia - 11\%). The 
inhabitants of Muntenia-Oltenia prefer Central Cluj $(27 \%)$ as well as the neighboring areas - Muntenia $(16 \%)$ and Oltenia (13\%), while people from Moldova are attracted by Crișana (19\%) and Central Mureș (13\%). The inhabitants of Dobrogea choose Western and central areas (Central Cluj -27\%, and Crișana- 20\%). The sea side is an option for them, too, $13 \%$, equally situated from Oltenia. The respondents in Banat-Crișana feel closely attached to the nearby region (Crișana, 23\%), but their first option remains Central Cluj area (24\%), followed by Central Brașov, fairly distant (14\%) and the Sea side $(10 \%)$. The inhabitants of Transylvania feel mainly attracted by Central Cluj (25\%), Crișana area (19\%) and the Sea side $(18 \%)$. They are also interested in Central Mureș (14\%) and Central Brașov (10\%).

\section{Conclusions}

As an effect of the complete data processing by means of the survey on the subject about the values, perception and attitudes of the potential medical domestic tourists in reference to the medical tourist offer in Romania, we received valuable feed-backs to our initially established goals.

a) The objective of identifying the interest, intention and motivation of the respondents in reference to the medical tourism. We found out that $93 \%$ of all respondents confirmed their option for medical travelling to another city in Romania, the score being of (5.31) on the scale showing the importance of including tourist services in a medical travel and consequently demonstrating that the Romanians are interested in medical tourism.

According to the results of the survey, the most important reasons why Romanians are interested in making a trip for medical purposes, are similar to the general reasons identified based on the literature review. These are linked to the possibility of having access to a medical specialization which is not available in their area of residence $(21 \%)$, the popularity of a clinic (19\%), confidence in a specialist $(42 \%)$ or getting a second medical opinion $(16 \%)$.

The results also emphasize an existing gender influence over the motivation of a medical tourist travel. To support the affirmation that Romanians are interested in medical tourism comes also the result confirming that most of them are disposed to travel on distances longer than $200 \mathrm{~km}(63 \%$ for over $300 \mathrm{~km}$ and $13 \%$ between $200 \mathrm{~km}$ and $300 \mathrm{~km}$ ). According to our survey, the stay is organized by a travel agency (45\%), the rest of $54 \%$ choosing to personally organize it, pointing out that in this case, age may influence the organizer's option. Consequently, persons over 55 are showing a higher confidence in specialized travel agencies.

As for financing a medical tourist travel, the Romanians choose to apply to the National Health Insurance House (54\%), followed by the preference for using the holiday vouchers, as well as private medical insurances (individual, or offered by the employer). The applied statistic methods have proved that, in this situation, the education level offers a different perspective of the financing options, according to its influence; the highly educated persons prefer an individual way of financing their travels, as the National Health Insurance House comes last.

Another aspect internationally studied by the specialized literature is the information channel referring to the medical tourism. The mostly appreciated ways used by Romanians to get information are the internet and the doctor's recommendation or advice, while the classic ways to promote tourism come last (tourist fairs, radio-TV programs, other promotion materials).

The conclusions of this survey also highlight the connection between medical tourism and other touristic possibilities, based on the studied population. From this point of view, medical tourism is best associated with the balneary one, followed by the leisure and recreation tourism and ecotourism.

b) The objective of establishing the level of confidence in the medical specialization of certain cities. The results of the survey show two main poles of the examined cities the Romanians mostly trust: Bucharest and Cluj-Napoca. These cities have been remarked due to the respondent's confidence in their capacity of treating medical affections in cardiology, orthopedic traumatic conditions, or oncology. Plastic and esthetic surgery, as well as recovery, physical and balneary medicine are mostly associated with cities like Bucharest or Oradea. Statistical methods have revealed that the region of residence can influence the confidence in a medical city, but we must consider the geographic position of their neighboring limit within some other regions.

c) The objective of evaluating the level of knowledge and the general perception regarding the specificity of the treatment in the spa resorts in the area of the galaxy clusters (medical label). From the 
analysis of the answers to the applied questionnaire, we concluded that the therapeutic profile of the spas is partially or not at all known, given that we ignore the proportion of answers in the category "I do not know". The "I don't know" appreciation varies from over $16 \%$ for the Sea side cluster to $52 \%$ for AradMoneasa cluster. Information concerning the West Arad-Moneasa cluster, combined with the wrong indications about the therapeutic profile of the spa reveal a higher need of the Romanian population knowledge improvement, or a modified perception concerning balneary treatment.

d) The objective of identifying travel preferences in certain medical tourist destinations (destination map). The central region of Romania proves the most attractive, together with the Central cluster: Cluj is pointed as the first for visiting, followed by the Central clusters of Mureș and Brașov. The hierarchy is completed by the West and South-West of Romanian clusters around the cities of Oradea and Timișoara. Moldova-Iași cluster and West-Arad come on the last positions. From the analysis of the results we also concluded that there is a significant interdependence of the region of residence and the intention to visit the areas represented by the galaxy clusters.

\section{Limitations}

In view of the present research, which, due to human, financial and time constraints, has not succeeded in under-sampling each region, it is recommended that for a clearer picture of the attitudes, values or perceptions of the population regarding medical tourism internal of Romania, in a future research, to carry out a stratified survey with representativeness on each historical region in which the respondents have their residency. For the same reasons, in future research on a national and regional level, a better result can be obtained if sampling involves the inclusion of an equal number of women and men, as well as the establishment of more detailed age subgroups that also involve a number of equal respondents.

\section{References}

1. Cravidão, F. N. Tourism at world heritage sites: Opportunities and Challenge [internet]; 2018. Available from/at https://www.fun-mooc.fr/

2. Gesundheitswirtschaft - Kompakte Vielfalt!. 9. Nationale Branchenkonferenz Gesundheitswirtschaft [internet]. Rostock, Germany; 2013. Available from/at: http://www.bioconvalley.org
3. Bookman M., \& Bookman K. Medical tourism in developing countries. New York: Palgarve Macmillan. 2007

4. Ile, F.L., Țigu, G. Medical tourism market trends - an exploratory research. In volume of 11 th International Conference on Business Excellence - Strategy, Complexity and Energy in Changing Times, De Gruyter. 2017; 11 (1): 1111-1121, doi:10.1515/picbe-2017-0114.

5. World Tourism Organization and European Travel Commission. Exploring Health Tourism. Madrid: UNWTO. 2018. Available from/at: doi: https://doi.org/10.18111/9789284420209

6. European Commission. First EU citizens using ePrescriptions in other EU country. 2019. Available at/from: http://europa.eu/rapid/press-release_IP-186808_en.htm (Accesed at 10.02. 2019).

7. Acorn Consulting. Developing a Niche Tourism Market Database for the Caribbean. 20 Niche Market Profiles. Acorn Consulting Partnership Ltd. 2008. Available at/from: https://www.onecaribbean.org/wpcontent/uploads/NicheMarketsDatabase.pdf

8. Vasile (Ile), F., Toma (Simoni), S. \& T,igu, G. Promoting Romania as a medical tourism destination - facts and challenges. In volume of BASIQ International Conference New Trends in Sustainable Business and Consumption. 4th ed. Heidelberg: ASE Publishing; 2018; 391-397.

9. Directiva 2011/24/UE a Parlamentului European și a Consiliului, publicată în Jurnalul Oficial al Uniunii Europene, 2011.

10. ARTM. Home - Asociația Română de Turism Medical. 2018. Available at/from: https://artm.ro/

11. Iliaș, A. Turismul medical însănătoșește piața horeca. 2016. Available at/from: https:/www.trendshrb.ro/actual/turismul-medicalinsanatoseste-piata-horeca

12. WTTC. Domestic Tourism - Importance \& Economic Impact. London: World Travel \& Tourism Council; 2018.

13. Hudson, S. \& Li, X. Domestic medical tourism: A neglected dimension of medical tourism research. In Medical Tourism and Wellness: Hospitality Bridging Healthcare $(\mathrm{H} 2 \mathrm{H})$, Series: Advances in Hospitality and Tourism, DeMicco, F. (ed.), New York: Apple Academic Press; 2017; 159-181,

14. Baloglu, S. \& McCleary, K. A model of destination image formation. Annals of Tourism Research; 1999; 26(4):868897.

15. Stoleriu, O. \& Ibănescu, B. Romania’s Country Image In Tourism TV Commercials. In volume of International Multidisciplinary Scientific Conferences on Social Sciences and Arts - SGEM 2015, Political Sciences, Law, Finance, Economics and Tourism, Conference proceedings, Section Economics and Tourism. 2015; Vol. 2; 867- 874. 


\section{Figures and tables}

Table 1. The 11 galaxy cluster medical tourism areas

\begin{tabular}{|l|l|l|}
\hline Heading level & Region & Galaxy Cluster \\
\hline Macroregion 3 & Bucharest Ilfov + South & Muntenia: Bucharest - Pucioasa - Slănic Prahova - Amara \\
\hline Macroregion 2 & North East & Moldova: Iași - Slănic Moldova - Târgu Ocna \\
\hline Macroregion 1 & North West & Center Cluj Napoca - Băile Turda - Ocna Șugatag - Sângeorz Băi \\
\hline Macroregion 4 & West & Banat: Timișoara - Buziaș - Băile Herculane \\
\hline Macroregion 1 & Center & Center Mureș - Sovata - Vatra Dornei - Sângeorz Băi \\
\hline Macroregion 4 & South West & Oltenia: Craiova - Olănești - Călimănești Căciulata - Govora \\
\hline Macroregion 1 & North West & Crișana: Oradea - Băile Felix \\
\hline Macroregion 4 & West & Vest: Arad- Moneasa \\
\hline Macroregion 1 & Center & Center Sibiu: Sibiu - Ocna Sibiului - Geoagiu Băi \\
\hline Macroregion 1 & Center & Center Brașov: Brașov - Băile Tușnad - Covasna \\
\hline Macroregion 2 & South East & Littoral: Constanța - Eforie - Techirghiol - Mangalia \\
\hline
\end{tabular}

Table 2. The relationship between the motivation of the trip for a medical tourist stay and the gender of person

\begin{tabular}{|c|c|c|c|c|c|c|c|c|}
\hline \multicolumn{9}{|c|}{ GENDER * MOTIVATION Crosstabulation } \\
\hline & & & \multicolumn{5}{|c|}{ MOTIVATION } & \multirow{2}{*}{ Total } \\
\hline & & & Famous clinic & Reliable doctor & Lack of the specialization & Second opinion & Other & \\
\hline \multirow{6}{*}{$\begin{array}{l}\text { GEN } \\
\text { DER }\end{array}$} & \multirow{3}{*}{ Male } & Count & 81 & 123 & 69 & 30 & 3 & 306 \\
\hline & & $\begin{array}{l}\% \text { within } \\
\text { MOTIV }\end{array}$ & $37,5 \%$ & $26,1 \%$ & $30,3 \%$ & $17,2 \%$ & $14,3 \%$ & $27,6 \%$ \\
\hline & & \begin{tabular}{|l|} 
Adjusted \\
Residual \\
\end{tabular} & 3,6 &,- 9 & 1,0 & $-3,3$ & $-1,4$ & \\
\hline & \multirow{3}{*}{ Female } & Count & 135 & 348 & 159 & 144 & 18 & 804 \\
\hline & & $\begin{array}{l}\% \text { within } \\
\text { MOTIV }\end{array}$ & $62,5 \%$ & $73,9 \%$ & $69,7 \%$ & $82,8 \%$ & $85,7 \%$ & $72,4 \%$ \\
\hline & & $\begin{array}{l}\text { Adjusted } \\
\text { Residual }\end{array}$ & $-3,6$ & ,9 & $-1,0$ & 3,3 & 1,4 & \\
\hline \multirow{2}{*}{\multicolumn{2}{|c|}{ Total }} & Count & 216 & 471 & 228 & 174 & 21 & 1110 \\
\hline & & $\begin{array}{l}\% \text { within } \\
\text { MOTIV }\end{array}$ & $100,0 \%$ & $100,0 \%$ & $100,0 \%$ & $100,0 \%$ & $100,0 \%$ & $100,0 \%$ \\
\hline
\end{tabular}

Table 3. Chi-Square Tests

\begin{tabular}{|l|l|l|l|}
\hline & \multicolumn{1}{|c|}{ Value } & \multicolumn{1}{c|}{ df } & \multicolumn{1}{c|}{ Asymp. Sig. (2-sided) } \\
\hline Pearson Chi-Square & $23,146^{\mathrm{a}}$ & 4 &, 000 \\
\hline Likelihood Ratio & 23,683 & 4 &, 000 \\
\hline Linear-by-Linear Association & 15,225 & 1 &, 000 \\
\hline N of Valid Cases & 1110 & & \\
\hline
\end{tabular}

a. 0 cells $(0,0 \%)$ have expected count less than 5 . The minimum expected count is 5,79 .

Table 4. ANOVA

\begin{tabular}{|l|l|l|l|l|l|}
\hline \multicolumn{1}{|c|}{ MOTIVATION } & \multicolumn{1}{c|}{ Mean Square } & \multicolumn{1}{c|}{ F } & \multicolumn{1}{c|}{ Sig. } \\
\hline Between Groups & \multicolumn{1}{|c|}{ Sum of Squares } & 1 & 16,032 & 15,423 & \\
\hline Within Groups & 16,032 & 1108 & 1,040 & & \\
\hline Total & 1151,770 & 1109 & & & \\
\hline
\end{tabular}

Table 5. The relationship between age and the preferred way of organizing a medical tourist stay

Mod_ORGZ * VARSTA Crosstabulation

\begin{tabular}{|c|c|c|c|c|c|c|}
\hline & & & \multicolumn{3}{|c|}{ AGE } & \multirow{2}{*}{ Total } \\
\hline & & & Gr_under 25 years & Gr_25-55 years & Gr_over 55 years & \\
\hline \multirow{6}{*}{ Mod_ORGZ } & \multirow{2}{*}{ Individual_orgz } & Count & 231 & 345 & 27 & 603 \\
\hline & & \% within Mod_ORGZ & $38,3 \%$ & $57,2 \%$ & $4,5 \%$ & $100,0 \%$ \\
\hline & \multirow{2}{*}{ TAgSpecialized_orgz } & Count & 159 & 288 & 48 & 495 \\
\hline & & \% within Mod_ORGZ & $32,1 \%$ & $58,2 \%$ & $9,7 \%$ & $100,0 \%$ \\
\hline & \multirow{2}{*}{ Other } & Count & 0 & 9 & 3 & 12 \\
\hline & & \% within Mod_ORGZ & $0,0 \%$ & $75,0 \%$ & $25,0 \%$ & $100,0 \%$ \\
\hline & \multirow[b]{2}{*}{ Total } & Count & 390 & 642 & 78 & 1110 \\
\hline & & $\begin{array}{l}\text { \% within } \\
\text { Mod_ORGZ }\end{array}$ & $35,1 \%$ & $57,8 \%$ & $7,0 \%$ & $100,0 \%$ \\
\hline
\end{tabular}


Table 6. Chi-Square Tests

\begin{tabular}{|l|l|l|l|}
\hline & Value & df & Asymp. Sig. (2-sided) \\
\hline Pearson Chi-Square & $24,001^{\text {a }}$ & 4 &, 000 \\
\hline Likelihood Ratio & 26,233 & 4 &, 000 \\
\hline Linear-by-Linear Association & 16,227 & 1 &, 000 \\
\hline N of Valid Cases & 1110 & & \\
\hline a. 2 cells $(22,2 \%)$ have expected count less than 5. The minimum expected count is , 84. \\
\hline
\end{tabular}

Table 7. ANOVA

\begin{tabular}{|c|l|l|l|l|l|}
\hline Mod_ORGZ & df & Mean Square & F & Sig. \\
\hline Between Groups & Sum of Squares & 5,391 & 2 & 2,695 & 10,116 \\
\hline Within Groups & 294,942 & 1107 &, 266 & & \\
\hline Total & 300,332 & 1109 & & & \\
\hline
\end{tabular}

Table 8. The relationship between the level of studies and the preferences regarding the way of financing the medical tourist stay

\begin{tabular}{|c|c|c|c|c|c|c|}
\hline \multicolumn{7}{|c|}{ FUNDING * STUDIES Crosstabulation } \\
\hline & & & \multicolumn{3}{|c|}{ STUDIES } & \multirow{2}{*}{ Total } \\
\hline & & & General & Medium & Superior & \\
\hline \multirow{21}{*}{ FUNDING } & \multirow{3}{*}{ Decont_CNAS } & Count & 0 & 222 & 378 & 600 \\
\hline & & \% within STUDIES & $0,0 \%$ & $63,2 \%$ & $50,2 \%$ & $54,1 \%$ \\
\hline & & Adjusted Residual & $-2,7$ & 4,2 & $-3,7$ & \\
\hline & \multirow{3}{*}{ Tickets_Holiday } & Count & 0 & 48 & 171 & 219 \\
\hline & & $\%$ within STUDIES & $0,0 \%$ & $13,7 \%$ & $22,7 \%$ & $19,7 \%$ \\
\hline & & Adjusted Residual & $-1,2$ & $-3,4$ & 3,6 & \\
\hline & \multirow{3}{*}{ PA_employer } & Count & 0 & 27 & 84 & 111 \\
\hline & & \% within STUDIES & $0,0 \%$ & $7,7 \%$ & $11,2 \%$ & $10,0 \%$ \\
\hline & & Adjusted Residual &,- 8 & $-1,7$ & 1,9 & \\
\hline & \multirow{3}{*}{ PA_individually } & Count & 3 & 24 & 51 & 78 \\
\hline & & \% within STUDIES & $50,0 \%$ & $6,8 \%$ & $6,8 \%$ & $7,0 \%$ \\
\hline & & Adjusted Residual & 4,1 &,- 2 &,- 5 & \\
\hline & \multirow{3}{*}{ Decont_CNP } & Count & 0 & 6 & 24 & 30 \\
\hline & & \% within STUDIES & $0,0 \%$ & $1,7 \%$ & $3,2 \%$ & $2,7 \%$ \\
\hline & & Adjusted Residual &,- 4 & $-1,4$ & 1,4 & \\
\hline & \multirow{3}{*}{ Personal_payment } & Count & 3 & 21 & 45 & 69 \\
\hline & & \% within STUDIES & $50,0 \%$ & $6,0 \%$ & $6,0 \%$ & $6,2 \%$ \\
\hline & & Adjusted Residual & 4,5 &,- 2 &,- 5 & \\
\hline & \multirow{3}{*}{ Other } & Count & 0 & 3 & 0 & 3 \\
\hline & & \% within STUDIES & $0,0 \%$ & $0,9 \%$ & $0,0 \%$ & $0,3 \%$ \\
\hline & & Adjusted Residual &,- 1 & 2,6 & $-2,5$ & \\
\hline \multirow{2}{*}{\multicolumn{2}{|c|}{ Total }} & Count & 6 & 351 & 753 & 1110 \\
\hline & & \% within STUDIES & $100,0 \%$ & $100,0 \%$ & $100,0 \%$ & $100,0 \%$ \\
\hline
\end{tabular}

Table 9. Chi-Square Tests

\begin{tabular}{|l|l|l|l|}
\hline & Value & df & Asymp. Sig. (2-sided) \\
\hline Pearson Chi-Square & $68,413^{\mathrm{a}}$ & 12 &, 000 \\
\hline Likelihood Ratio & 54,310 & 12 &, 000 \\
\hline Linear-by-Linear Association &, 165 & 1 &, 685 \\
\hline N of Valid Cases & 1110 & & \\
\hline a. 9 cells (42,9\%) have expected count less than 5. The minimum expected count is ,02. & \\
\hline
\end{tabular}

Table 10. ANOVA

\begin{tabular}{|c|c|c|c|c|c|}
\hline \multicolumn{6}{|c|}{ FUNDING } \\
\hline & Sum of Squares & df & Mean Square & $\mathrm{F}$ & Sig. \\
\hline Between Groups & 59,269 & 2 & 29,635 & 13,609 &, 000 \\
\hline Within Groups & 2410,655 & 1107 & 2,178 & & \\
\hline Total & 2469,924 & 1109 & & & \\
\hline
\end{tabular}


Table 11. How to inform about medical tourism

\begin{tabular}{|c|l|c|}
\hline Position & How to find out/inform & Final score \\
\hline $\mathbf{1}$ & Internet & 2720 \\
\hline $\mathbf{2}$ & Doctor & 2750 \\
\hline $\mathbf{3}$ & Friends' recommendations & 3724 \\
\hline $\mathbf{4}$ & Tourism fairs & 4567 \\
\hline $\mathbf{5}$ & Radio TV shows & 4646 \\
\hline $\mathbf{6}$ & Magazines, leaflets, brochures, catalogs, posters & 4831 \\
\hline
\end{tabular}

Table 12. Frequency distribution on combining forms of tourism

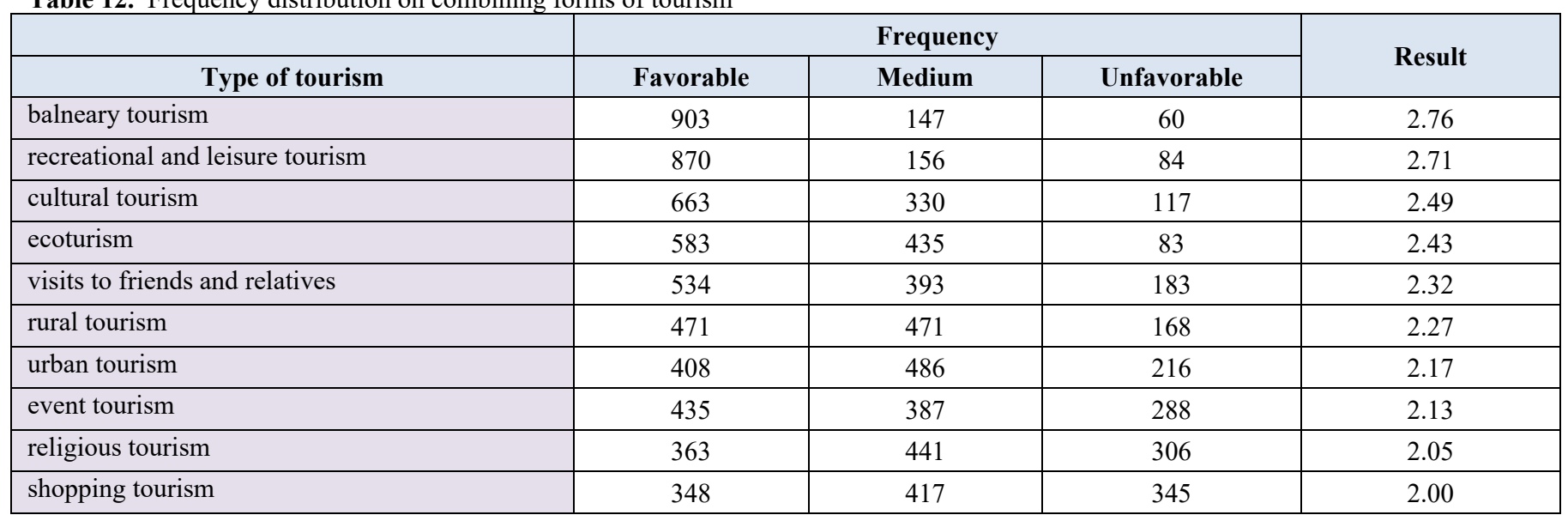

Table 13. Hierarchy of regions regarding the intention to visit

\begin{tabular}{|c|c|c|}
\hline Position & Galaxy clusters & $\begin{array}{c}\text { Final } \\
\text { score }\end{array}$ \\
\hline $\mathbf{1}$ & Cluj Napoca - Băile Turda - Ocna Șugatag- Sângeorz Băi & 4719 \\
\hline $\mathbf{2}$ & Târgu Mureș - Sovata - Vatra Dornei & 5668 \\
\hline $\mathbf{3}$ & Brașov - Băile Tușnad - Covasna & 5770 \\
\hline $\mathbf{4}$ & Oradea - Băile Felix & 5851 \\
\hline $\mathbf{5}$ & Timișoara -Băile Herculane - Buziaș & 6023 \\
\hline $\mathbf{6}$ & Constanța - Eforie - Techirghiol - Mangalia & 6177 \\
\hline $\mathbf{7}$ & Sibiu - Ocna Sibiului - Geoagiu Băi & 6200 \\
\hline $\mathbf{8}$ & Bucharest - Pucioasa - Slănic Prahova - Amara & 7476 \\
\hline $\mathbf{9}$ & Craiova - Olănești - Călimănești Căciulata - Govora & 7773 \\
\hline $\mathbf{1 0}$ & Iași - Slănic Moldova - Târgu Ocna & 7944 \\
\hline $\mathbf{1 1}$ & Arad - Moneasa & 9177 \\
\hline
\end{tabular}

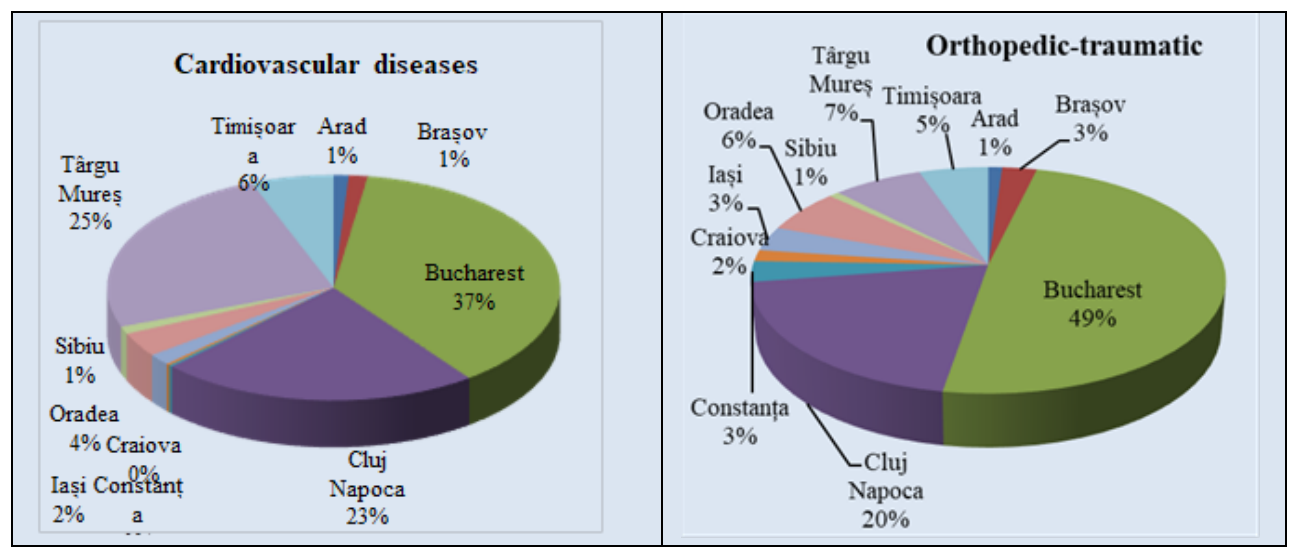

Figure 1. Perception of confidence/relience in the treatment of cardiovascular and orthopedic-traumatic diseases 


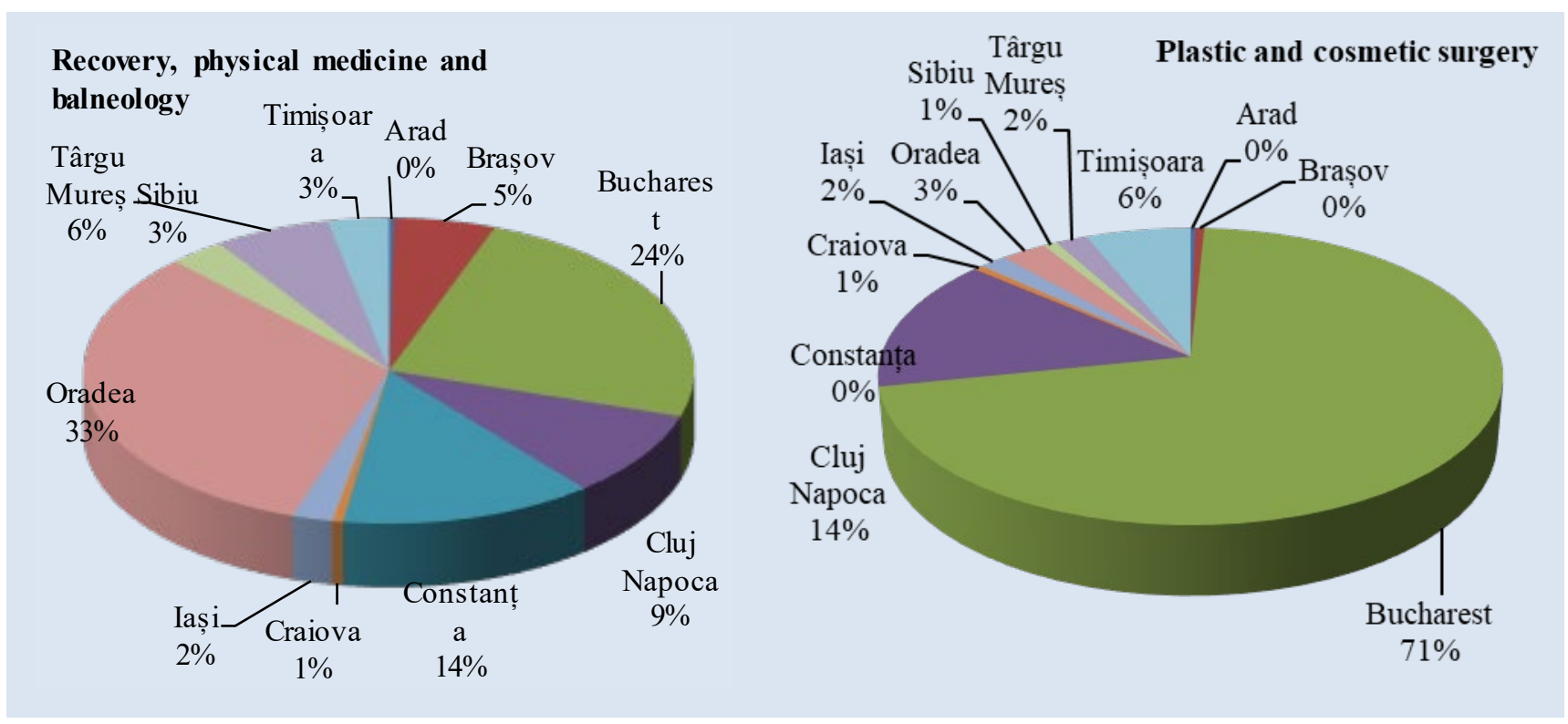

Figure 2. Reliance on plastic surgery and recovery medicine services

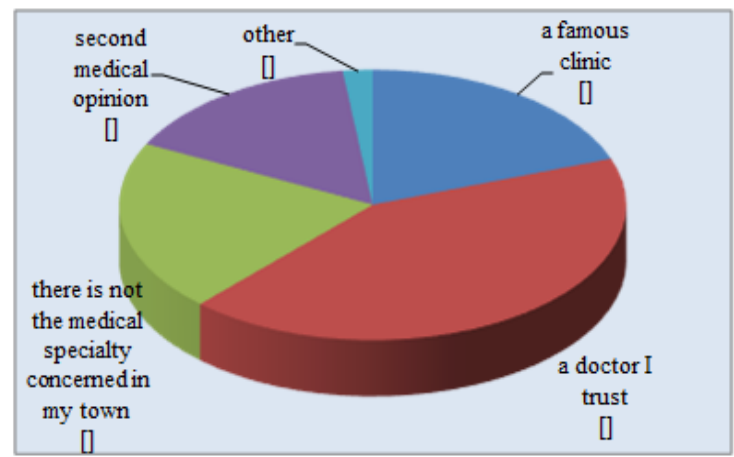

Figure 3. Factors motivating travel for medical purposes

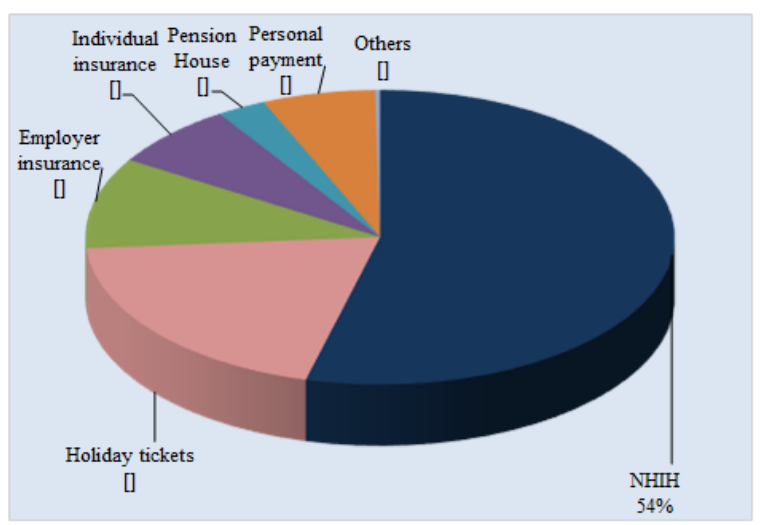

Figure 5. Preferences regarding the

financing/settlement system of the medical tourist stay

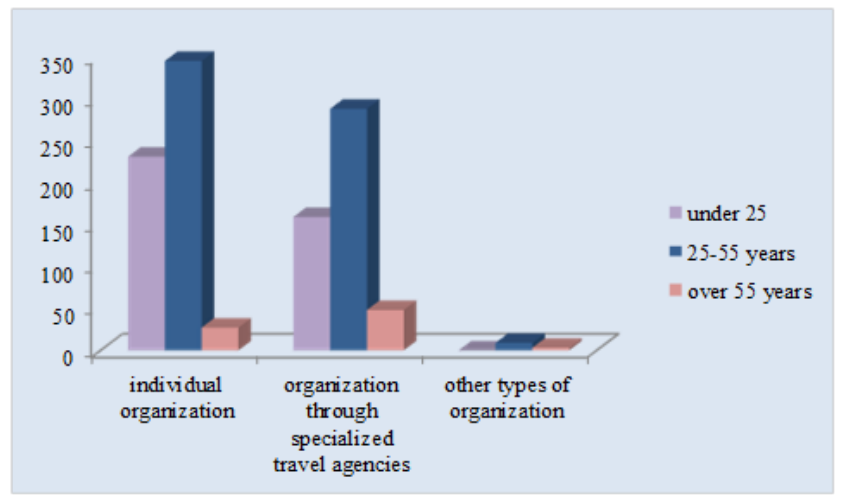

Figure 4. Distribution of the preferred way of organizing the medical stay by age

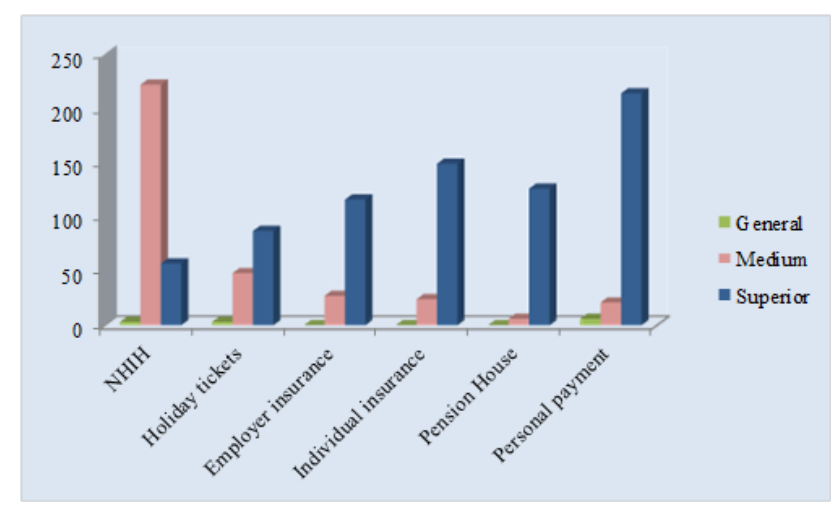

Figure 6. Differences between the level of studies and the preference regarding the type of financing of the medical stay 